\title{
Betaproteobacteria growth and nitrification rates during long-term natural dissolved organic matter decomposition experiments
}

\author{
Eva Teira ${ }^{1, *}$, Sandra Martínez-García ${ }^{1}$, Christian Lønborg ${ }^{2,3}$, \\ Xosé A. Álvarez-Salgado \\ ${ }^{1}$ Departamento de Ecoloxía e Bioloxía Animal, Universidade de Vigo, 36310 Vigo, Spain \\ ${ }^{2}$ CSIC, Instituto de Investigacións Mariñas, Eduardo Cabello 6, 36208 Vigo, Spain \\ ${ }^{3}$ Scottish Association for Marine Science, Oban, Argyll PA37 1QA, UK
}

\begin{abstract}
As a first attempt to relate net nitrification rates with bacterial community structure in the coastal embayment of the Ría de Vigo (NW Spain), a set of 6 long-term (lasting 53 to 74 d) dissolved organic matter decomposition experiments were conducted in the dark and at a constant temperature of $15^{\circ} \mathrm{C}$ with surface seawater collected in January, February, April, and June 2008. Net nitrification rates were estimated from nitrate concentration changes. Evolution of bacterial community composition was followed using catalyzed reporter deposition-fluorescent in situ hybridization (CARD-FISH) and specific probes for 6 relevant bacterial groups, including Beta- and Gammaproteobacteria. The growth rates of Betaproteobacteria showed a significant linear positive relationship with nitrification rates that explained $82 \%$ of the observed variability, which strongly suggests that the main nitrifying microorganisms during the incubations belonged to the Beta subclass of Proteobacteria. A positive relationship was found between net nitrification rates and both ammonium $\left(\mathrm{r}^{2}=0.92\right)$ and phosphate $\left(\mathrm{r}^{2}=0.97\right)$ concentrations, which suggests a tight link among the nitrogen and phosphorus cycles, likely as a result of the role of phosphate as the bacterial growth-limiting nutrient.
\end{abstract}

KEY WORDS: Betaproteobacteria $\cdot$ Nitrification $\cdot$ CARD-FISH

Resale or republication not permitted without written consent of the publisher

\section{INTRODUCTION}

One of the most challenging goals in ecosystem ecology is to unravel the links between biogeochemical processes and biological community composition. In the sea, the nitrogen cycle depends on the metabolic activities of selected prokaryotes (Karl \& Michaels 2001). Nitrification is the microbial mediated process by which ammonium is oxidized to nitrate. This process influences the partition of $\mathrm{N}$ among various pools and may lead to loss of fixed $\mathrm{N}$ from the system. Coupled nitrification-denitrification removes up to $50 \%$ of external dissolved inorganic $\mathrm{N}$ inputs to estuaries (Seitzinger et al. 2006), which reduces the risk of eutrophication in these sensitive areas. Bacteria con- tributing to ammonia oxidation, the rate-limiting step of nitrification, belong to the subclass Betaproteobacteria (genera Nitrosomonas and Nitrosospira) and Gammaproteobacteria (genus Nitrosococcus). The second step of nitrification, nitrite-oxidation, is carried out by a variety of bacteria belonging to different subclasses of Proteobacteria (Alpha-, Beta-, and Gamma-) and by the genus Nitrospira (Zehr \& Ward 2002).

Several groups of Betaproteobacteria able to oxidize ammonia are commonly found in marine and estuarine systems (O'Mullan \& Ward 2005). The potential for significant ammonia oxidation by mesophilic Crenarchaea has been also demonstrated in terrestrial, marine, and wastewater treatment environments (see review by Prosser \& Nicol 2008). Growing evidence 
suggests that Archaea would prevail over bacteria under limiting ammonium and phosphate concentrations, in low $\mathrm{pH}$ sulfidic environments, and in low salinity estuarine sediments with high C:N ratios (Mosier \& Francis 2008, Erguder et al. 2009, MartensHabbena et al. 2009).

A dependence of nitrification rates upon ammonium concentration is usually not observed in natural assemblages (Ward 1987, 2002). This lack of correlation has been attributed to very high affinities of ammoniaoxidizers for ammonium or to changes in the ammoniaoxidizing bacterial community composition (Ward 2005).

Rates of nitrification in the Ría de Vigo (NW Spain) obtained from nutrient budgets have been estimated to be remarkably high compared with other coastal upwelling systems, providing about $50 \%$ of the nitrate consumed in the photic layer in this upwelling ecosystem (Álvarez-Salgado \& Gilcoto 2004). However, the microorganisms involved in nitrification processes have never been studied in this highly productive coastal system. As a first attempt to relate nitrification rates with bacterial community structure in this area, we conducted a set of 6 long-term (53 to $74 \mathrm{~d}$ ) dissolved organic matter decomposition experiments with surface seawater collected from the central segment of the Ría de Vigo under contrasting hydrographic conditions in January, February, April, and June 2008. We focused on bacteria, as we hypothesized that Archaea likely play a minor role in this marine eutrophic system.

Net nitrification rates were estimated from the net increase of nitrate concentrations during the course of the experiments. Changes in bacterial community composition were followed using catalyzed reporter deposition-fluorescent in situ hybridization (CARDFISH) and specific probes for 6 relevant groups, including Beta- and Gammaproteobacteria. Despite the limitations (reduced turbulence, darkness, and altered grazer communities) of these in vitro field experiments, nitrification rates have been directly linked to groupspecific bacterial growth rates.

\section{MATERIALS AND METHODS}

Sample collection. Water for the laboratory incubation experiments was collected from a fixed station in the middle segment of the Ría de Vigo $\left(42^{\circ} 14.09^{\prime} \mathrm{N}, 8^{\circ} 47.18^{\prime} \mathrm{W}\right)$ in winter (31 January, 7 and 14 February 2008), spring (17 and 24 April 2008), and summer (26 June 2008) with an acid-washed 251 Niskin bottle at $5 \mathrm{~m}$ depth. Salinity and temperature profiles were recorded prior to water collection with an SBE 9/11 CTD probe.

Experimental design. Filtration of the sample water started within $10 \mathrm{~min}$ of collection; one part was fil- tered through a dual-stage (0.8 and $0.2 \mu \mathrm{m})$ filter cartridge (Pall-Acropak Supor Membrane) which had been pre-washed with 101 of Milli-Q water; the second part was filtered through pre-combusted $\left(450^{\circ} \mathrm{C}\right.$ for $4 \mathrm{~h}) \mathrm{GF} / \mathrm{C}$ filters to collect the bacterial community $(<1.2 \mu \mathrm{m}$ size fraction). After filtration, the water was kept in the dark until arrival in the base laboratory, within $2 \mathrm{~h}$ of collection. The $0.2 \mu \mathrm{m}$ filtrate was transferred into a 201 carboy, and the bacterial community (i.e. the $1.2 \mu \mathrm{m}$ filtrate) was added in a proportion corresponding to $10 \%$ of the total volume. The water was distributed into 24 glass bottles $(500 \mathrm{ml})$, with 4 replicate bottles being analyzed on Days $0,1,2,4,12$, and 53 or 74 (summer experiment only). The glass bottles were kept in the dark at a constant temperature of $15^{\circ} \mathrm{C}$ in the 6 experiments. All glassware was acidwashed and rinsed with Milli-Q water prior to use. Samples for the analysis of the dissolved phase were collected from each of the 4 replicate incubation bottles by filtration through $0.2 \mu \mathrm{m}$ filters (Pall, Supor Membrane Disc Filter) to follow ammonium $\left(\mathrm{NH}_{4}^{+}\right)$, nitrite $\left(\mathrm{NO}_{2}^{-}\right)$, nitrate $\left(\mathrm{NO}_{3}^{-}\right)$, phosphate $\left(\mathrm{HPO}_{4}{ }^{2-}\right)$, and dissolved organic carbon (DOC) concentrations. Water samples for nutrient analyses were collected in $50 \mathrm{ml}$ acid-washed polyethylene bottles and kept frozen $\left(-20^{\circ} \mathrm{C}\right)$ until analysis. Aliquots for DOC analysis were collected in $10 \mathrm{ml}$ pre-combusted $\left(450^{\circ} \mathrm{C}, 12 \mathrm{~h}\right)$ glass ampoules and preserved by adding $50 \mu \mathrm{l} 25 \% \mathrm{H}_{3} \mathrm{PO}_{4}$. Subsamples for the bacterial community were collected on Days $0,1,2,4$, and 53 or 74 .

Chemical analyses. DOC samples were measured using a Shimadzu TOC-CSV organic carbon analyzer (Pt-catalyst). To avoid the small error associated with day-to-day instrument variability, all samples from a given experiment were analyzed on a single day. The instrument was checked daily against the deep Sargasso Sea reference water $(2600 \mathrm{~m})$ provided by the laboratory of D. A. Hansell (Miami, FL, USA). We obtained a mean \pm SD concentration of $46.0 \pm 2.0 \mu \mathrm{mol}$ $\mathrm{C}^{-1}$ while the nominal value provided by the refer-

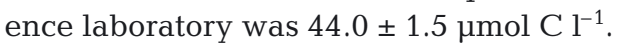

For the same set of experiments discussed here, Lønborg et al. (2010) adjusted the kinetics of DOC utilization to a first-order exponential decay function using the Marquardt-Levenberg algorithm and taking the refractory pool into account:

$$
\mathrm{DOC}=\mathrm{BDOC} \times \exp \left(-\mathrm{k}_{\mathrm{DOC}} \times t\right)+\mathrm{RDOC}
$$

where DOC $(t)$ is the concentration of DOC at incubations times $0,4,12$, and $53-74 \mathrm{~d}$, BDOC is the bioavailable DOC pool $\left(\mu \mathrm{mol} \mathrm{l}^{-1}\right), \mathrm{k}_{\mathrm{DOC}}$ is the degradation rate constant $\left(\mathrm{d}^{-1}\right), t$ is time (in days), and RDOC is the refractory DOC pool $\left(\mu \mathrm{mol} \mathrm{l}^{-1}\right)$. RDOC was defined as the concentration at the end of the incubation time (53 or $74 \mathrm{~d}$ ) and BDOC as the difference between the ini- 
tial DOC concentration and RDOC. Since BDOC and RDOC are calculated prior to adjusting the time evolution of $\mathrm{DOC}(t)$, the only parameter that is adjusted with Eq. (1) is $\mathrm{k}_{\mathrm{DOC}}$.

Nutrient salts were determined by standard colorimetric methods with an Alpkem segmented flow analyzer (SFA) (Grasshoff et al. 1983). A 4-point calibration curve of potassium nitrate with concentrations ranging from 0 to $15 \mu \mathrm{mol} \mathrm{l}^{-1}$ was used to standardize the nitrate+nitrite SFA method, based on the reduction to nitrite in a $\mathrm{Cu} / \mathrm{Cd}$ column followed by the determination of nitrite by the standard methods of azoic salt. Nitrite was measured simultaneously, and the concentration of nitrate was obtained by subtracting the nitrite concentration of the sample divided by the yield of the reduction column to the nitrate+nitrite concentration. The accuracy of the method is $\pm 0.1 \mu \mathrm{mol} \mathrm{l} \mathrm{l}^{-1}$ and the curve is linear up to $30 \mu \mathrm{mol} \mathrm{l}^{-1}$. Net nitrification rates (in $\mu \mathrm{mol}$ $\mathrm{m}^{-3} \mathrm{~d}^{-1}$ ) were calculated from the accumulation of nitrate during the course of each experiment by subtracting the initial from the final nitrate concentration and dividing by the incubation time.

Bacterial community composition. Fifteen ml were fixed by adding $0.2-\mu \mathrm{m}$ filtered formaldehyde (1 to $2 \%$ final concentration) and the samples were subsequently stored at $4^{\circ} \mathrm{C}$ in the dark for 12 to $18 \mathrm{~h}$. Thereafter, each sample was filtered through a $0.2 \mu \mathrm{m}$ polycarbonate filter (Millipore, GTTP, $25 \mathrm{~mm}$ filter diameter) supported by a cellulose nitrate filter (Millipore, HAWP, $0.45 \mu \mathrm{m})$, washed twice with Milli-Q water, dried, and stored in a microfuge vial at $-20^{\circ} \mathrm{C}$ until further treatment in the laboratory.

Bacterial community composition changes were monitored using CARD-FISH techniques as described by Teira et al. (2008) with a mix of oligonucleotide probes specific for the domain Eubacteria (EUB338, EUB338II, EUB338III; Daims et al. 1999), the Beta(BET42a) (Manz et al. 1992) and Gammaproteobacteria (GAM42a) (Manz et al. 1992) subclasses, and the class Flavobacteria of phylum Bacteroidetes (CF319a) (Manz et al. 1996). Additionally, the relative abundance of the SAR11, Roseobacter, and SAR86 clusters was also analyzed using the specific probes SAR11-441R (Morris et al. 2002), Ros537 (Eilers et al. 2001), and SAR86/1245 (Zubkov et al. 2001). The Eub antisense probe Non338 probe was used as a negative control.

Filters for CARD-FISH were embedded in lowgelling-point agarose and incubated with lysozyme. Filters were cut in sections and hybridized at $35^{\circ} \mathrm{C}$ with horseradish peroxidase (HRP)-labeled oligonucleotide probes over 4 to $12 \mathrm{~h}$. Tyramide-Alexa488 was used for signal amplification (30 to $40 \mathrm{~min}$ ). We used 55\% of formamide for all probes except SAR11-441R (45\% formamide). Cells were counter-stained with a DAPI-mix (5.5 parts of Citifluor, 1 part of Vectashield, and 0.5 parts of phosphate-buffered saline with DAPI, final concentration $1 \mu \mathrm{g} \mathrm{ml}^{-1}$ ).

The slides were examined under a Leica DMBL microscope equipped with a $100 \mathrm{~W} \mathrm{Hg}$ lamp and appropriate filter sets for DAPI and Alexa488. More than 800 DAPI-stained cells were counted per sample. For each microscope field, 2 different categories were enumerated: (1) total DAPI-stained cells, (2) cells stained with the specific probe. Negative control counts (hybridization with HRP-Non338) averaged $0.5 \%$ of DAPI-stained cells. The counting error, expressed as the percentage of standard error between replicates, was on average $<5 \%$ for DAPI counts and $<10 \%$ for FISH counts. The counting error was relatively higher (33\%) for the less abundant groups (Betaproteobacteria and SAR86).

Group-specific bacterial net growth rates over the full incubation period were estimated using the logistic equation:

$$
N=K n /[1+\exp (\mathrm{a}-\mu \times t)]
$$

where $N$ represents cell abundance (cells $\mathrm{ml}^{-1}$ ), Kn is the cell abundance at the end of the experiment (Day 53 or 74), a is a constant parameter, $t$ is the time (d), and $\mu$ is the growth rate $\left(\mathrm{d}^{-1}\right)$. Student's $t$-test was used to assess whether the derived growth rates were significantly higher than 0 .

\section{RESULTS AND DISCUSSION}

The percentage of detected bacteria (EUB-positive cells) slightly increased during the incubation in January and February. By contrast, during the experiments conducted in April and June, the percentage of detected bacteria significantly decreased (Fig. 1). The set of 6 FISH probes used accounted on average for 85 and $80 \%$ of total detected bacteria at the beginning and at the end of the experiments, respectively.

The initial bacterial community was dominated by the group Bacteroidetes, except in January, when the group SAR11 was the most abundant (Fig. 1). The dominance of Bacteroidetes has been widely reported in productive marine pelagic systems (Riemann et al. 2000, Alderkamp et al. 2006, Teira et al. 2008). The dominance of SAR11 in January was related to the entry of DOC-poor Eastern North Atlantic Central Water into the Ría de Vigo associated with the upwelling-downwelling dynamics of this embayment (Teira et al. 2009). The relative abundance of Beta- and Gammaproteobacteria, which include several nitrifying bacteria, was low at the beginning of the experiments (on average 2 and $4 \%$ of DAPI counts, respectively). Betaproteobacteria significantly increased their relative abundances during the incubation time in all 

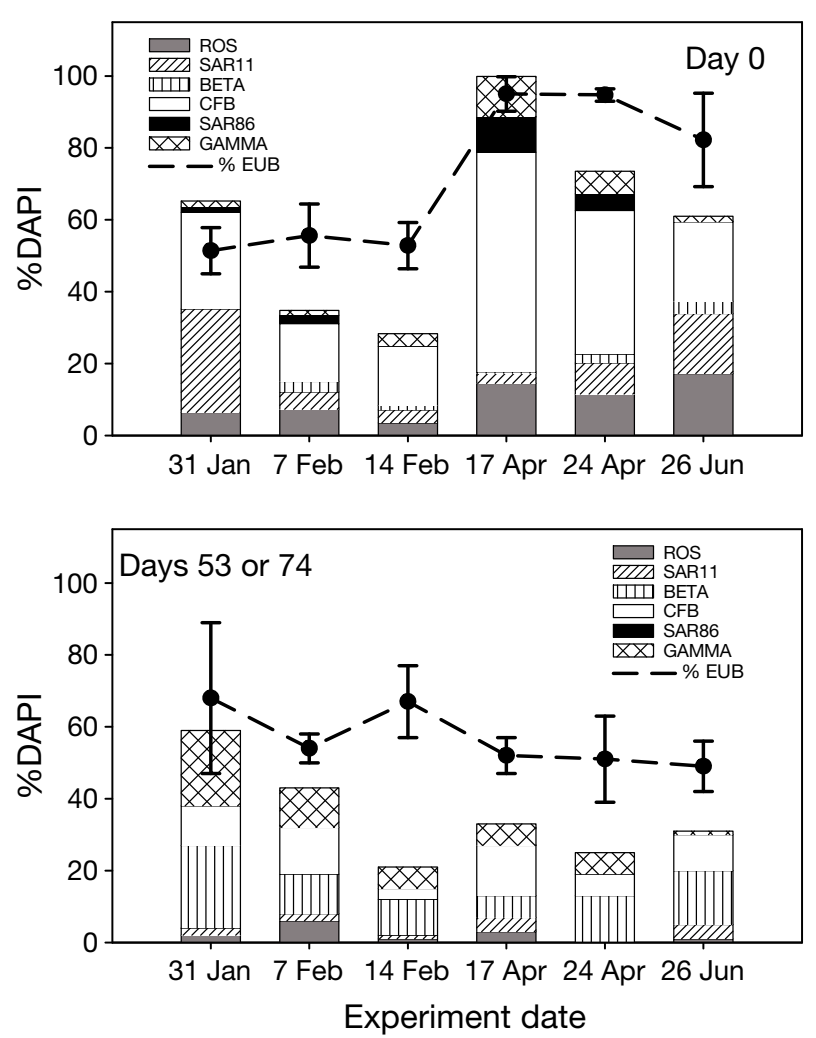

Fig. 1. Composition of the bacterial assemblage at the beginning (Day 0) and at the end (Days 53 or 74) of 6 incubation experiments conducted in 2008. The relative abundance of each group (ROS: Roseobacter; SAR11; BETA: Betaproteobacteria; CFB: Bacteroidetes; SAR86; GAMMA: Gammaproteobacteria) is expressed as a percentage of total DAPIstained cells. The dashed black line represents the percentage of prokaryotes detected with the mix of oligonucleotide probes specific for the domain Eubacteria (EUB). Error bars represent $\pm \mathrm{SE}$

experiments ( $t$-test, $\mathrm{p}<0.045$ ), accounting for up to $23 \%$ of DAPI-counts at the end of the experiment conducted in January. The Gammaproteobacteria showed a significantly higher relative abundance at the end than at the beginning of the experiment conducted in January ( $t$-test, $\mathrm{p}=0.012)$. All other groups either remained constant ( $t$-test, $\mathrm{p}>0.05$ ) or showed a significant decrease in their relative abundances ( $t$-test, $\mathrm{p}<0.05)$.

In most cases, the concentration of nitrate did not change much over the first $12 \mathrm{~d}$ of incubation; it accumulated between Days 12 and 50 (Fig. 2). Exceptions to this trend were Expts 1 and 2 (where a linear increase was observed) and 5 (where a logarithmic increase was observed). For this reason, we decided to calculate the net nitrification rate just by subtracting the initial from the final nitrate concentration and dividing by the incubation time. Net nitrification rates ranged from 6 to $103 \mu \mathrm{mol} \mathrm{NO} \mathrm{N}_{3} \mathrm{~m}^{-3} \mathrm{~d}^{-1}$, being higher in winter than in spring and summer. Although the net nitrification rates derived from our incubations were within the range of previous estimates by Álvarez-Salgado \& Gilcoto (2004) for the same region, the highest rate was 1 order of magnitude lower than the highest nitrification rate $\left(1400 \mu \mathrm{mol} \mathrm{NO} \mathrm{NO}^{-3} \mathrm{~d}^{-1}\right)$ calculated by these authors under natural field conditions. It is important to note the significant methodological differences between our study (10\% dilution bacterial cultures, long incubations, dark conditions) and that by Álvarez-Salgado \& Gilcoto (2004) (in situ nutrient budgets), which preclude us from directly comparing the magnitude of nitrification during both studies. Nevertheless, the measured nitrification rates agreed very well with those rates of ammonium oxidation measured by Ward (2005) over a 2 yr study in Monterey Bay, California, USA ( $<20$ to ca. $80 \mu \mathrm{mol} \mathrm{m} \mathrm{m}^{-3} \mathrm{~d}^{-1}$ ), using the ${ }^{15} \mathrm{~N}$ trace method during 3 to $6 \mathrm{~h}$ incubations under simulated in situ conditions.

Betaproteobacteria net growth rates over the whole incubation period ( 53 or $74 \mathrm{~d}$ ) were calculated from the time-course of their absolute abundances in the 6 experiments using a logistic equation (Fig. 3). All net growth estimates were significantly higher than 0 except that of the 24 April experiment, and ranged from 0.4 to $1.4 \mathrm{~d}^{-1}$ (Table 1). The determination coefficient of the adjusted models ranged from 0.85 to 0.99 . Higher net growth rates were measured in winter than in spring and summer. The net growth rate of Gammaproteobacteria was significantly different from 0 only in the experiment conducted in January $\left(0.46 \mathrm{~d}^{-1}\right)$. As mentioned before, the abundance of all other groups remained stable or decreased during the incubations, showing a positive net growth only for 1 to $2 \mathrm{~d}$.

The net growth rates of Betaproteobacteria showed a significant linear positive relationship with the net nitrification rates (Fig. 4A). Furthermore, the net growth of this bacterial group explained $82 \%$ of the variability observed in net nitrification rates, which strongly suggests that the main nitrifying microorganisms during our incubations belong to the Beta subclass of Proteobacteria. Although both Beta- and Gammaproteobacteria include ammonia-oxidizing bacteria (AOB), which carry out the limiting step in nitrification, it has been observed that Gammaproteobacteria AOB are not very abundant in seawater (O'Mullan \& Ward 2005). Nonetheless, Lam et al. (2007) found that despite their low abundance, ammonia-oxidizing Gammaproteobacteria can significantly contribute to nitrification in the Black Sea suboxic zone.

The potential major role of Archaea as ammonia-oxidizing microorganisms has recently been reported in several environments. From the available information on the potential niches of ammonia-oxidizing Archaea (AOA) and AOB, we presumed that Archaea do not 


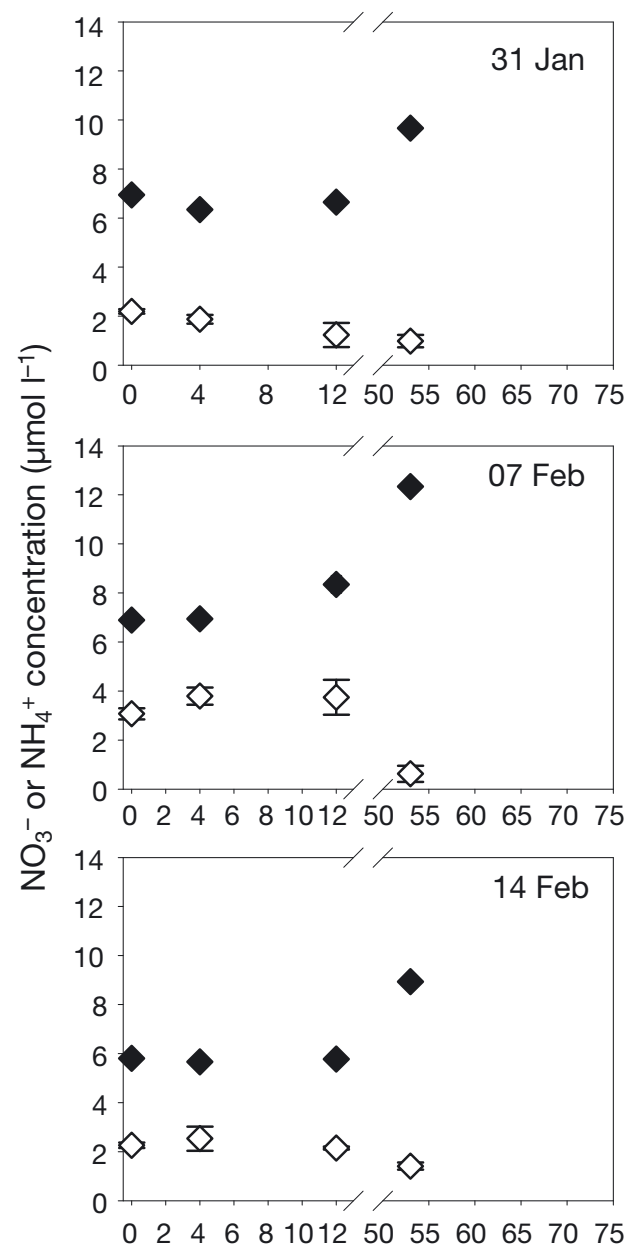

Day

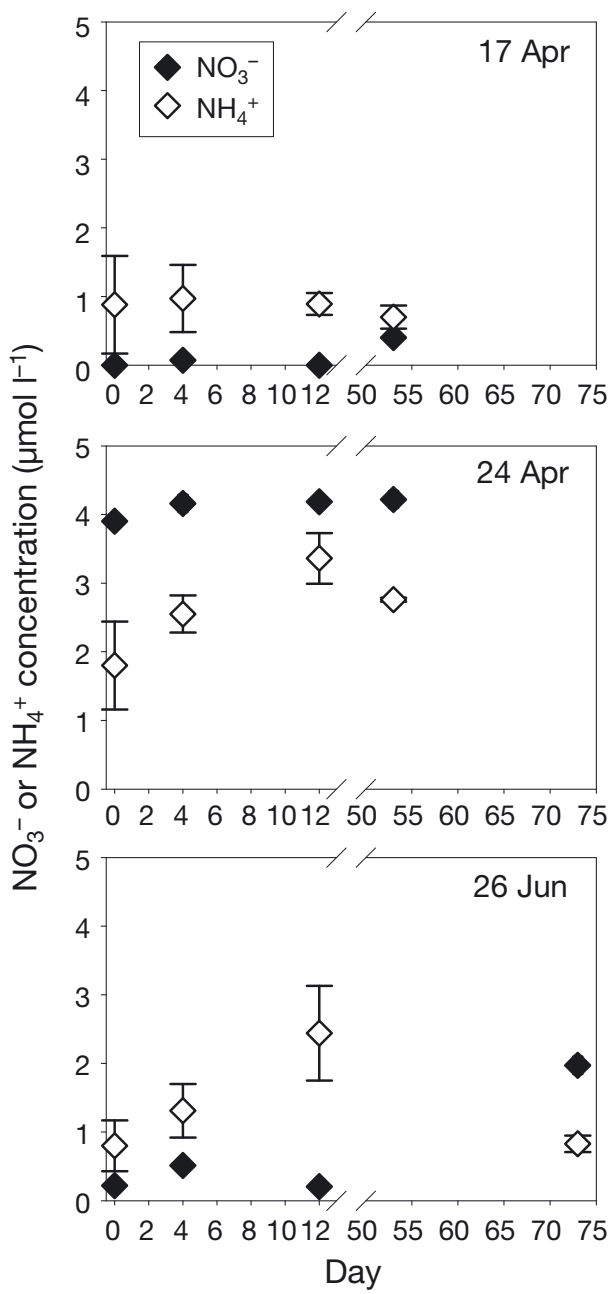

Fig. 2. Time course of nitrate and ammonium concentration during 6 dilution experiments conducted in 2008. Error bars represent \pm SD from 4 replicates. Note the different scales for the 17 April, 24 April, and 26 June experiments

play a relevant role in nitrification in this eutrophic pelagic ecosystem (Mosier \& Francis 2008, Di et al. 2009, Erguder et al. 2009, Martens-Habbena et al. 2009). Assuming that CARD-FISH detection rates were

Table 1. Betaproteobacteria (Beta) growth rates, nitrification rates, and dissolved organic carbon degradation rate $\left(\mathrm{k}_{\mathrm{DOC}}\right)$ $( \pm \mathrm{SE})$ estimated for 6 experiments conducted in 2008. $\mathrm{k}_{\mathrm{DOC}}$ values were taken from Lønborg et al. (2010). NS: not significantly different from 0

\begin{tabular}{|lcrc|}
\hline $\begin{array}{l}\text { Date } \\
(2008)\end{array}$ & $\begin{array}{c}\text { Beta growth } \\
\left(\mathrm{d}^{-1}\right)\end{array}$ & $\begin{array}{c}\text { Nitrification } \\
\left(\mu \mathrm{mol} \mathrm{NO} \mathrm{m}^{-3} \mathrm{~d}^{-1}\right)\end{array}$ & \multicolumn{1}{c|}{$\begin{array}{c}\mathrm{k}_{\mathrm{DOC}} \\
\left(\mathrm{d}^{-1}\right)\end{array}$} \\
\hline $31 \mathrm{Jan}$ & $1.1 \pm 0.2$ & $51 \pm 7$ & $0.11 \pm 0.03$ \\
$7 \mathrm{Feb}$ & $1.2 \pm 0.1$ & $103 \pm 5$ & $0.11 \pm 0.01$ \\
$14 \mathrm{Feb}$ & $0.9 \pm 0.2$ & $59 \pm 4$ & $0.20 \pm 0.01$ \\
$17 \mathrm{Apr}$ & $0.4 \pm 0.1$ & $8 \pm 1$ & $0.20 \pm 0.02$ \\
$24 \mathrm{Apr}$ & $0.5 \pm 0.4(\mathrm{NS})$ & $6 \pm 4$ & $0.20 \pm 0.02$ \\
$26 \mathrm{Jun}$ & $0.5 \pm 0.1$ & $24 \pm 2$ & $0.30 \pm 0.08$ \\
\hline
\end{tabular}

equal or even lower on Days 53 or 74 than on Day 0 , the fact that in the winter experiments (31 January, 7 and 14 February) the initial contribution of bacteria to total prokaryotic abundance $(52,55$, and $53 \%$, respectively) did not significantly decrease from its contribution at the end of the incubations $(68,54$, and $67 \%$, respectively; $t$-test, $\mathrm{p}>0.16$ ) suggests that Archaea did not grow considerably in our experimental bottles. By contrast, the relative abundance of bacteria significantly decreased ( $t$-test, $p<0.05$ ) at the end of the incubation in the experiments conducted in spring and summer (from 95, 95, and $82 \%$ at the beginning to 52, 51 , and $49 \%$ at the end on 17 and 24 April and 26 June, respectively), which might indicate an increase in archaeal abundance. Unfortunately, we do not have information about the abundance and the community composition of Archaea in our experiments, which precludes us from speculating about their potential role as nitrifiers in the Ría de Vigo. 

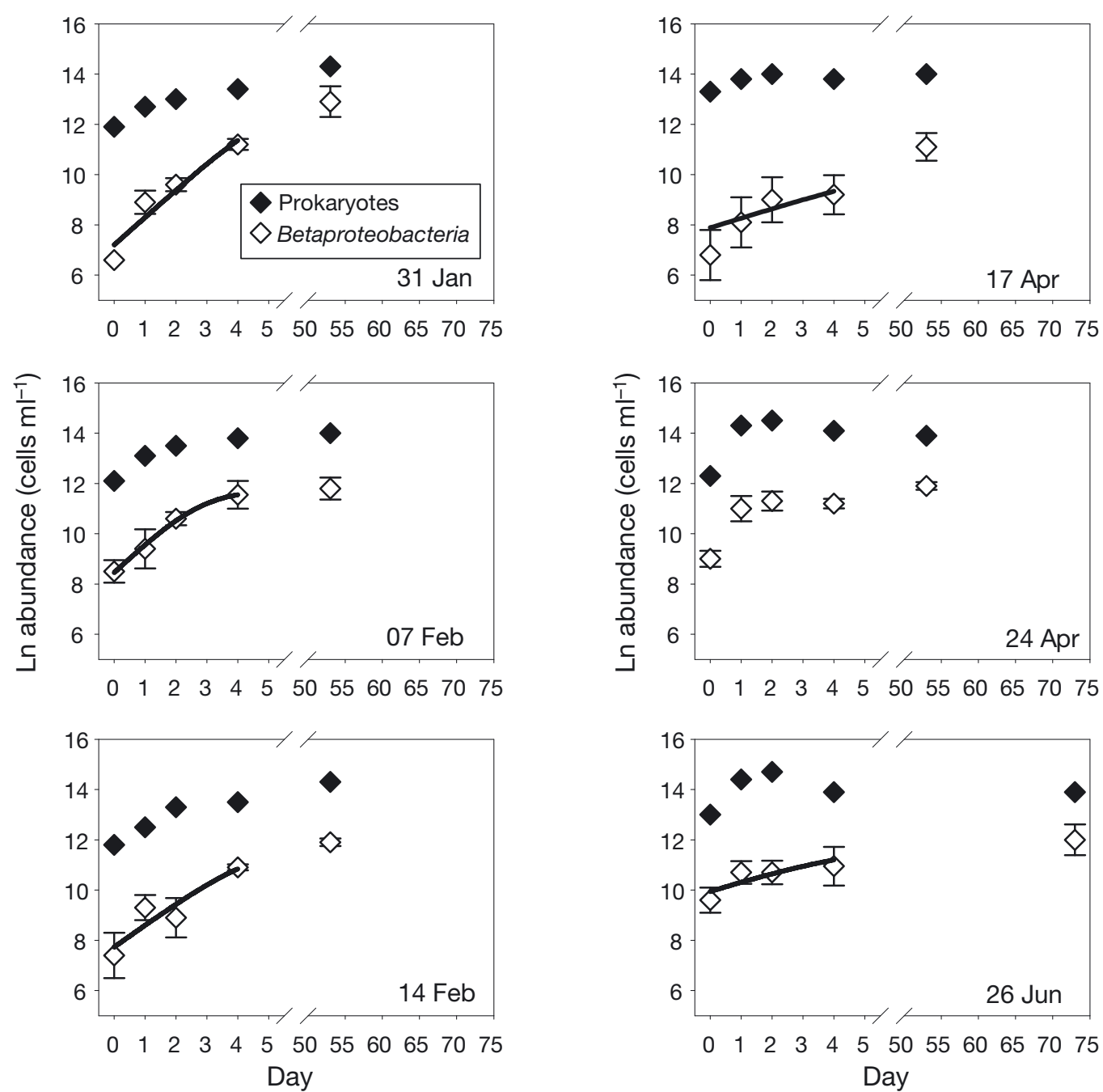

Fig. 3. Time course of prokaryotic abundance (DAPI-stained cells) and Betaproteobacteria abundance during 6 dilution experiments conducted in 2008. Error bars represent \pm SE from 2 replicates. For clarity, the adjusted logistic growth curve (black line) for Betaproteobacteria has been drawn only between Days 0 and 4
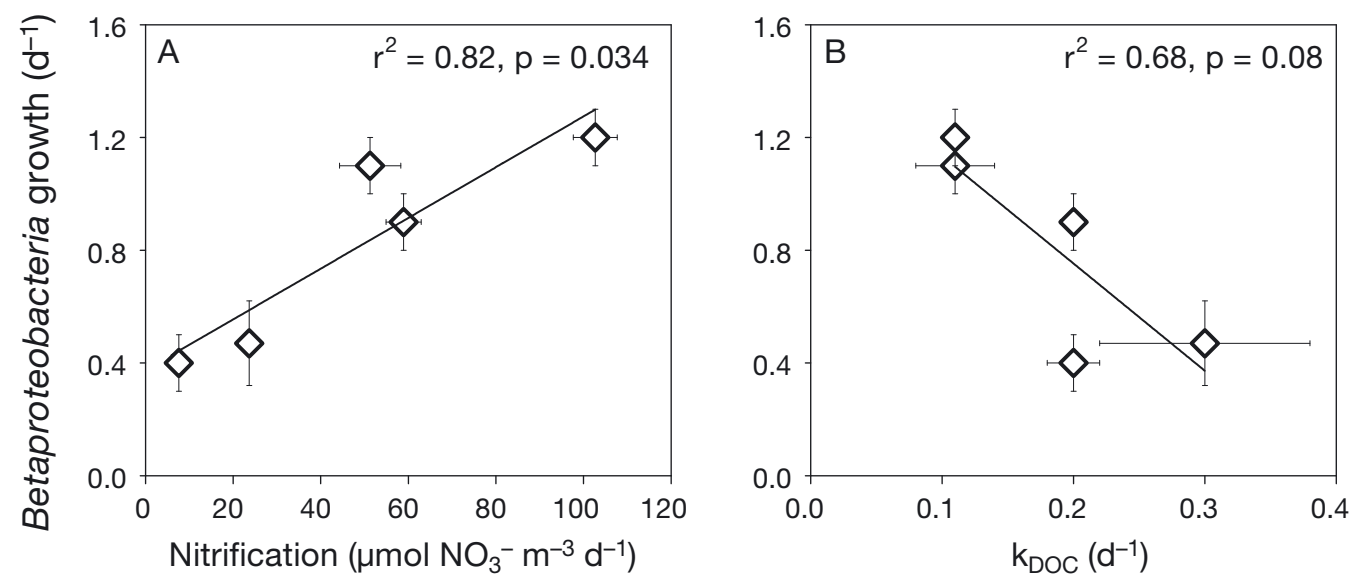

Fig. 4. Relationship between Betaproteobacteria growth and (A) nitrification rates $(y=0.009 x+0.37)$ or (B) dissolved organic carbon (DOC) degradation rates ( $\mathrm{k}_{\mathrm{DOC}} \mathrm{y}=-3.8 x+1.51$ ). Errors bars represent $\pm \mathrm{SE}$ from 2 (Betaproteobacteria growth) or 4 (nitrification and DOC degradation rates) replicates. Data point from 24 April was excluded due to no significant growth rate (see Table 1) 
Table 2. Environmental conditions at the sampling site (5 $\mathrm{m}$ depth) in the Ría de Vigo on the water collection dates in 2008. Temp: temperature, Chl a: chlorophyll a, DOC: dissolved organic carbon

\begin{tabular}{|c|c|c|c|c|c|c|c|}
\hline $\begin{array}{l}\text { Date } \\
(2008)\end{array}$ & Salinity & $\begin{array}{l}\text { Temp } \\
\left({ }^{\circ} \mathrm{C}\right)\end{array}$ & $\begin{array}{c}\text { Chl a } \\
\left(\mu \mathrm{g} \mathrm{l}^{-1}\right)\end{array}$ & $\begin{array}{c}\mathrm{HPO}_{4}{ }^{2-} \\
\left(\mu \mathrm{mol} \mathrm{l}{ }^{-1}\right)\end{array}$ & $\begin{array}{c}\mathrm{NO}_{3}^{-} \\
\left(\mu \mathrm{mol} \mathrm{l} l^{-1}\right)\end{array}$ & $\begin{array}{c}\mathrm{NH}_{4}^{+} \\
\left(\mu \mathrm{mol} \mathrm{l}^{-1}\right)\end{array}$ & $\begin{array}{c}\text { DOC } \\
\left(\mu \mathrm{mol} \mathrm{l}^{-1}\right)\end{array}$ \\
\hline 31 Jan & 35.0 & 13.0 & 1.52 & $0.46 \pm 0.01$ & $6.9 \pm 0.1$ & $2.2 \pm 0.1$ & $75 \pm 1$ \\
\hline 7 Feb & 34.5 & 13.1 & 0.81 & $0.56 \pm 0.01$ & $6.9 \pm 0.1$ & $3.2 \pm 0.1$ & $77 \pm 1$ \\
\hline $14 \mathrm{Feb}$ & 35.2 & 13.4 & 1.13 & $0.42 \pm 0.01$ & $5.8 \pm 0.1$ & $2.3 \pm 0.1$ & $73 \pm 1$ \\
\hline 17 Apr & 34.8 & 14.3 & 3.04 & $0.09 \pm 0.02$ & $0.1 \pm 0.1$ & $0.9 \pm 0.7$ & $81 \pm 1$ \\
\hline $24 \mathrm{Apr}$ & 25.0 & 15.5 & 8.42 & $0.02 \pm 0.01$ & $3.9 \pm 0.1$ & $1.8 \pm 0.6$ & $85 \pm 1$ \\
\hline 26 Jun & 35.1 & 17.4 & 4.32 & $0.27 \pm 0.01$ & $0.2 \pm 0.1$ & $0.8 \pm 0.1$ & $88 \pm 1$ \\
\hline
\end{tabular}

The derived maximum net growth rate for Betaproteobacteria was within the range of reported rates for ammonia ( 0.48 to $2.11 \mathrm{~d}^{-1}$ ) and nitrite-oxidizing bacteria (0.43 to $1.39 \mathrm{~d}^{-1}$; Prosser 2007), and was also similar to maximum growth rates of the AOA 'Candidatus Nitrosopumilus maritimus' strain SCM1 (MartensHabbena et al. 2009). AOB are autotrophic bacteria that use ammonium as their sole source of energy, and carbon dioxide as a carbon source, which results in rather inefficient growth. Therefore, it is generally accepted that the growth rate of nitrifying bacteria is significantly lower than that of heterotrophic bacteria. This can certainly be true under culture conditions. However, the growth rates of nitrifying bacteria reported in natural conditions are not remarkably lower than the range of growth rates reported for heterotrophic bacteria in marine waters (Yokokawa et al. 2004, Teira et al. 2009).

It is possible that not all of the Betaproteobacteria detected with CARD-FISH are nitrifiers and, thus, autotrophic; however, the high positive correlation with nitrification and the negative marginally significant $(\mathrm{p}=0.08)$ correlation with DOC degradation rates (Fig. 4B) strongly suggest that a significant fraction of the Betaproteobacteria detected during the incuba-

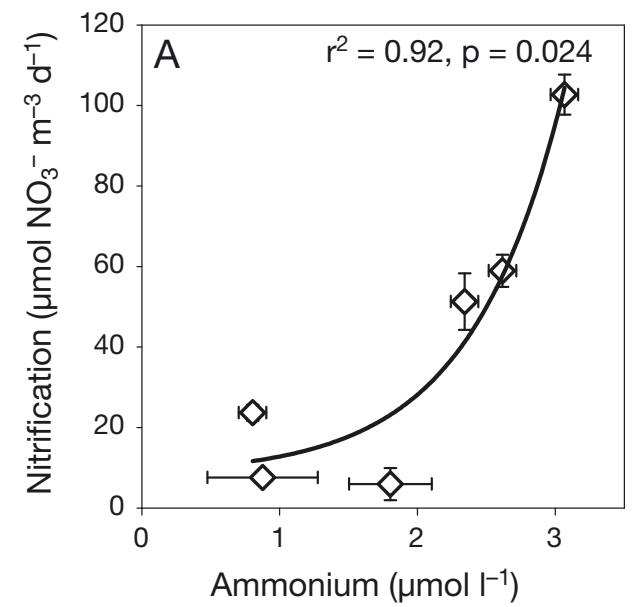

tions were autotrophic. The fact that Betaproteobacteria growth is lower as the DOC degradation rates are higher could reflect a direct competition of autotrophic and heterotrophic bacteria for the available ammonium. It has been reported that autotrophic ammonia oxidation can be either depressed (Verhagen et al. 1992) or enhanced (Clark \& Schmidt 1966) by heterotrophic bacteria. A recent study by Taylor \& Townsend (2010) suggests that heterotrophic bacteria would outcompete nitrifying bacteria for ammonium uptake under a situation of nitrogen limitation (high DOC: nitrate ratios). The highest DOC:nitrate ratios were found in the spring and summer experiments (Table 2). Thus, the low nitrification rates measured in spring and summer could result from heterotrophic bacteria outcompeting nitrifying bacteria.

Provided that ammonia oxidation is the limiting step in nitrification, both AOB growth rates and nitrification rates are expected to be directly linked to the availability of ammonium. We actually found a strong positive relationship $\left(\mathrm{r}^{2}=0.92\right)$ among the initial ammonium concentration and the nitrification rates (Fig. 5A). However, the relationship was not linear, and fitted better to a positive exponential model. Fig. 4A suggests that

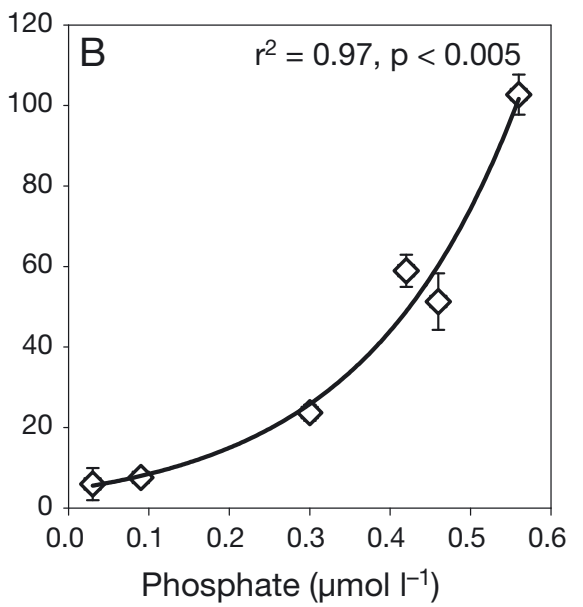

Fig. 5. Relationship between nitrification rates and (A) ammonium or (B) phosphate concentration at the beginning of the experiments. Error bars represent $\pm \mathrm{SE}$ from 4 replicates 
at low ammonium concentration $\left(<2 \mu \mathrm{mol}^{-1}\right)$, other factors were ultimately controlling nitrification rates. Most studies on environmental factors controlling nitrification in marine pelagic systems point to temperature, light, and oxygen concentrations, besides ammonium availability, as the main regulatory factors (de Bie et al. 2002, Andersson et al. 2006, Sugimoto et al. 2009). Regardless of the very limited range of variability in water temperature and initial oxygen concentration (Table 2) covered during our sampling period, the estimated nitrification rates varied by more than 1 order of magnitude (Table 1). In addition, all incubations were conducted in the dark and at a constant temperature $\left(15^{\circ} \mathrm{C}\right)$, suggesting that the aforementioned factors must play a minor role in explaining the variability in our dataset.

We explored the relationship of nitrification rates and other environmental variables such as salinity, DOC concentration, or phosphate concentration. We found that phosphate concentration explained $97 \%$ of the variability in nitrification rates (Fig. 5B). In fact, nitrification rates appear to be better explained by phosphate concentration when nutrients are in short supply. There is not much information about the effect of phosphate deficiency on nitrification. Herfort et al. (2007) also demonstrated a positive correlation between crenarchaeotal amoA gene copies and phosphate concentration in the southern North Sea. A positive correlation between nitrification or amoA gene copies and phosphate can merely reflect the role of phosphate as a bacterial growth-limiting nutrient (see review by Church 2008). The fact that during spring and summer, when the phosphate concentration was lower than in winter, the nitrification rates were low and the DOC degradation rates were high, suggests that a severe $\mathrm{P}$ deficiency may limit even more the ability of nitrifying bacteria to compete for $\mathrm{N}$ with heterotrophic bacteria. Purchase (1974) demonstrated the influence of phosphate deficiency on nitrification and concluded that nitrite oxidizers are more sensitive to $\mathrm{P}$ deficiency than ammonia oxidizers, which can severely affect their ability to compete for nitrogen, ultimately limiting nitrification. Our results thus demonstrate that nitrification depends not only on the availability of ammonia but also on the availability of phosphate.

\section{CONCLUSIONS}

Betaproteobacteria growth explained $82 \%$ of the observed variability in nitrification rates in the coastal eutrophic system of the Ría de Vigo, which highlights the role of members of this group as nitrifiers in this system. Nevertheless, further research is needed to simultaneously assess the potential role of both bacteria and Archaea.
Ammonium concentration explained $92 \%$ of the variability observed in nitrification rates in the Ría de Vigo, although phosphate also appears to be an important controlling factor, which implies a tight link between the nitrogen and phosphorus cycles.

Acknowledgements. This study was funded by a fellowship to C.L. from the Early Stage Training site ECOSUMMER (MEST-CT-2004-0205019). We thank the captain, crew, and technicians of RV 'Mytilus' and the members of the Department of Oceanography of the Instituto de Investigacións Mariñas for the collaboration during the sampling program. Access to vessel time and meteorological and hydrological data were provided by the RAFTING project (CTM200761983/MAR). S.M.G. was funded by an FPU-MEC fellowship. E.T. was funded by a Ramón y Cajal-MEC contract.

\section{LITERATURE CITED}

Alderkamp AC, Sintes E, Herndl GJ (2006) Abundance and activity of major groups of prokaryotic plankton in the coastal North Sea during spring and summer. Aquat Microb Ecol 45:237-246

Álvarez-Salgado XA, Gilcoto M (2004) Inferring nitrification rates with an inverse method in a coastal upwelling system, Ría de Vigo (NW Spain). Mar Ecol Prog Ser 276:3-17

Andersson MGI, Brion N, Middelburg JJ (2006) Comparison of nitrifier activity versus growth in the Scheldt Estuary a turbid, tidal estuary in northern Europe. Aquat Microb Ecol 42:149-158

Church MJ (2008) Resource control of bacterial dynamics in the sea. In: Kirchman DL (ed) Microbial ecology of the oceans, 2nd edn. Wiley-Liss, New York, NY, p 335-382

Clark C, Schmidt EL (1966) Effect of mixed culture on Nitrosomonas europaea simulated by uptake and utilization of pyruvate. J Bacteriol 91:367-373

> Daims H, Bruhl A, Amann R, Schleifer KH, Wagner M (1999) The domain-specific probe EUB338 is insufficient for the detection of all Bacteria: development and evaluation of a more comprehensive probe set. Syst Appl Microbiol 22: 434-444

De Bie MJM, Starink M, Boschker HTS, Peene JJ, Laanbroek HJ (2002) Nitrification in the Schelde estuary: methodological aspects and factors influencing its activity. FEMS Microbiol Ecol 42:99-107

> Di HJ, Cameron KC, Shen JP, Winefield CS, O'Callaghan M, Bowatte S, He JZ (2009) Nitrification driven by bacteria and not archaea in nitrogen-rich grassland soils. Nat Geosci 2:621-624

> Eilers H, Pernthaler J, Peplies J, Glöckner FO, Gerdts G, Amann R (2001) Isolation of novel pelagic bacteria from the German Bight and their seasonal contributions to surface picoplankton. Appl Environ Microbiol 67:5134-5142

Erguder TH, Boon N, Wittebolle L, Marzorati M, Verstraete W (2009) Environmental factors shaping the ecological niches of ammonia-oxidizing archaea. FEMS Microbiol Rev 33:855-869

Grasshoff K, Ehrhardt M, Kremling M (1983) Methods of seawater analysis, 2nd edn. Verlag Chemie, Weinheim

> Herfort L, Schouten S, Abbas B, Veldhuis MJW and others (2007) Variations in spatial and temporal distribution of Archaea in the North Sea in relation to environmental variables. FEMS Microbiol Ecol 62:242-257 
Karl DM, Michaels AF (2001) Nitrogen cycle. In: Steele JH, Turekian KK, Thorpe SA (eds) Encyclopedia of ocean sciences. Academic Press, London, p 1876-1884

Lam P, Jensen MM, Lavik G, McGinnis DF and others (2007) Linking crenarchaeal and bacterial nitrification to anammox in the Black Sea. Proc Natl Acad Sci USA 104: 7104-7109

Lønborg C, Álvarez-Salgado XA, Martínez-García S, Miller AEJ, Teira E (2010) Stoichiometry of dissolved organic matter and the kinetics of its microbial degradation in a coastal upwelling system. Aquat Microb Ecol 58:117-126

Manz W, Amann R, Ludwig W, Wagner M, Schleifer KH (1992) Phylogenetic oligodeoxynucleotide probes for the major subclasses of proteobacteria - problems and solutions. Syst Appl Microbiol 15:593-600

Manz W, Amann R, Ludwig W, Vancanneyt M, Schleifer KH (1996) Application of a suite of 16S rRNA-specific oligonucleotide probes designed to investigate bacteria of the phylum cytophaga-flavobacter-bacteroides in the natural environment. Microbiology 142:1097-1106

Martens-Habbena W, Berube PM, Urakawa H, de la Torre JR, Stahl DA (2009) Ammonia oxidation kinetics determines niche separation of nitrifying Archaea and Bacteria. Nature 461:976-979

Morris RM, Rappé MS, Connon SA, Vergin KL, Slebold WA, Carlson CA, Giovanonni SJ (2002) SAR11 clade dominates ocean surface bacterioplankton communities. Nature 420: $806-810$

Mosier AC, Francis CA (2008) Relative abundance and diversity of ammonia-oxidizing archaea and bacteria in the San Francisco Bay estuary. Environ Microbiol 10:3002-3016

O'Mullan GD, Ward BB (2005) Relationship of temporal and spatial variabilities of ammonia-oxidizing bacteria to nitrification rates in Monterey Bay, California. Appl Environ Microbiol 71:697-705

Prosser JI (2007) The ecology of nitrifying bacteria. In: Bothe $\mathrm{H}$, Ferguson SJ, Newton WE (eds) Biology of the nitrogen cycle. Elsevier, Amsterdam, p 223-243

Prosser JI, Nicol GW (2008) Relative contributions of archaea and bacteria to aerobic ammonia oxidation in the environment. Environ Microbiol 10:2931-2941

Purchase BS (1974) The influence of phosphate deficiency on nitrification. Plant Soil 41:541-547

Riemann L, Steward GF, Azam F (2000) Dynamics of bacterial community composition and activity during a

Editorial responsibility: Jed Fuhrman,

Los Angeles, California, USA mesocosm diatom bloom. Appl Environ Microbiol 66: $578-587$

Seitzinger S, Harrison JA, Böhlke JK, Bouwman AF and others (2006) Denitrification across landscapes and waterscapes: a synthesis. Ecol Appl 16:2064-2090

Sugimoto R, Kasai A, Miyajima T, Fujita K (2009) Controlling factors of seasonal variation in the nitrogen isotope ratio of nitrate in a eutrophic coastal environment. Estuar Coast Shelf Sci 85:231-240

Taylor PG, Townsend AR (2010) Stoichiometric control of organic carbon-nitrate relationships from soils to the sea. Nature 464:1178-1181

- Teira E, Gasol JM, Aranguren-Gassis M, Fernández A, González J, Lekunberri I, Álvarez-Salgado XA (2008) Linkages between bacterioplankton community composition, heterotrophic carbon cycling and environmental conditions in a highly dynamic coastal ecosystem. Environ Microbiol 10:906-917

Teira E, Martínez-García S, Lønborg C, Álvarez-Salgado XA (2009) Growth rates of different phylogenetic bacterioplankton groups in a coastal upwelling system. Environ Microbiol Rep 1:545-554

> Verhagen FJM, Duyts H, Laanbroek HJ (1992) Competition for ammonium between nitrifying and heterotrophic bacteria in continuously percolated soil columns. Appl Environ Microbiol 58:3303-3311

> Ward BB (1987) Nitrogen transformations in the Southern California Bight. Deep-Sea Res 34:785-805

Ward BB (2002) Nitrification in aquatic systems. In: Capone DG (ed) Encyclopedia of environmental microbiology. John Wiley \& Sons, New York, NY, p 2144-2167

- Ward BB (2005) Temporal variability in nitrification rates and related biogeochemical factors in Monterey Bay, California, USA. Mar Ecol Prog Ser 292:97-109

Yokokawa T, Nagata T, Cottrell MT, Kirchman DL (2004) Growth rate of the major phylogenetic bacterial groups in the Delaware estuary. Limnol Oceanogr 49:1620-1629

Zehr JP, Ward BB (2002) Nitrogen cycling in the ocean: new perspectives on processes and paradigms. Appl Environ Microbiol 68:1015-1024

Zubkov MV, Fuchs BM, Burkill PH, Amann R (2001) Comparison of cellular and biomass specific activities of dominant bacterioplankton groups in stratified waters of the Celtic sea. Appl Environ Microbiol 67:5210-5216

Submitted: April 13, 2010; Accepted: January 6, 2011

Proofs received from author(s): February 14, 2011 